\title{
ASSESSMENT OF THE ECONOMIC EFFECTIVENESS OF THE USE OF FINANCIAL RESOURCES FOR TRAINING OF THE UNEMPLOYED
}

\author{
Antra Salmane1, Anita Puzule ${ }^{2}$ \\ 1Mg.soc.sc., Rezekne Academy of Technologies, Rezekne, Latvia, \\ e-mail: Antra.Salmane@inbox.lv \\ ${ }^{2}$ Mg.oec., researcher, lecturer, Rezekne Academy of Technologies, Rezekne, Latvia, \\ e-mail: Anita.Puzule@rta.lv
}

\begin{abstract}
Along with the rapid development of technologies, demand on the labor market changes, still the skills and knowledge of jobseekers do not match the market needs. The State Employment Agency (hereinafter - SEA) implements training measures for the unemployed. Nevertheless, there is a problem that the unemployed involved in training do not always want to enter the labour market, or their knowledge acquired during the training is not useful. The aim of the study is to assess the economic efficiency of the financial resources allocated for training of the unemployed persons in the context of Latvia and its regions. Research methods: monographic method, graphical method, expert survey method, correlation and regression analysis. The authors explore the use of the financial resources allocated for training and analyse its economic efficiency in Latvia and Latvia's regions. It is found that the difference in unemployment rates in the statistical regions of Latvia has significantly increased during the study period. In order to facilitate the reintegration of individuals into the labour market, more funding is provided for training in the regions with higher unemployment rates. The economic efficiency of the use of financial resources varies from region to region, both in terms of the cost of training per unemployed person involved and the number of the trainees employed after the training, and of the funding for training used in the region.
\end{abstract}

Keywords: training programmes; the unemployed; finding employment; financial resources; State Employment Agency.

JEL code: E24; H43; H53; G18.

\section{Introduction}

Increasingly, the skills and knowledge of those seeking to enter the labour market do not meet the demand of the labour market. To help people adapt to the rapid economic change, the training programs have been offered to the unemployed persons by the SEA since 2008. Latvian National Development Plan 2014-2020 stipulates that the involvement of the unemployed persons and the employees in the adult education prevent and reduce unemployment, increase work productivity, create a basis for income increase and for self-realization (Latvian National Development Plan 20142020,2012 ). A problem is that the unemployed persons that are trained do not always want to enter the labour market, or their knowledge acquired is not used. 
The aim of the study is to evaluate the economic efficiency of funding used for training of the unemployed in the context of Latvia and its regions.

In order to achieve the aim, the following research tasks were set:

1) to study theoretical aspects of training of the unemployed individuals,

2) to assess the economic efficiency of the training programs implemented by the SEA for the unemployed,

3 ) to explore the integration of the unemployed persons into the labour market after participation in the training programs.

The research hypothesis - the funding used by the SEA for training programs for the unemployed is of a high economic efficiency. Participation of the unemployed in the training programs facilitates their reintegration into the labour market.

Novelty of the research - the authors study the use of funding for training, analyse its economic efficiency, and develop proposals for its improvement.

Research methods: monographic method, graphical method, expert survey method, correlation and regression analysis.

The research period is 2015-2018, though for analysis of some indicators a longer period is used. The research carried out is based on the scientific publications, analysis of regulatory enactments, data of the Ministry of Welfare (hereinafter - MoW), Central Statistical Bureau (CSB), SEA, Organization for Economic Cooperation and Development (hereinafter - OECD), as well as processed questionnaires of the expert interviews.

\section{Theoretical aspects of training of unemployed persons and analysis of unemployment}

The researches show that the unemployment is fuelled by a variety of economic processes in the country, leading to the labour surpluses or the labour that does not correspond to the employers' demand (Sfichi \& Bratiloveanu, 2017). Unemployment is a phenomenon that is important both at the macroeconomic level and at the individual level (Schonauer, 2016), and can have many significant consequences, such as lower quality of life of the unemployed persons and their families, increased social isolation, diminished self-confidence and self-esteem of the individuals (Aysina et al., 2016). The authors have observed that losing the job often leads to the psychological problems, which is noted also by Hodzic in his research, stating that the unemployed persons tend to have lower psychological and physical well-being and feel less satisfied with their lives in comparison with the 
employed individuals (Hodzic et al., 2015). Likewise, the chances of finding a job are impacted by the individuals' level of education, knowledge, work experience, as well as individual circumstances, such as infrastructure development, political and economic situation in the country (Grineviča, 2016), as well as the region of residence (Hazans, 2005).

The authors point out that an important factor in finding a job is the individual's willingness to work, as well as duration of unemployment. The long-term unemployed individuals may have a lack of motivation and unhealthy behaviours (Hodzic et al., 2015); they are exposed to the risk of exclusion and could become lasting clients of the social services (Laškova, 2012). The authors conclude that the long-term unemployed individuals often have various addiction problems that hinder their integration into the labour market.

The global financial crisis was followed by the increase of unemployment across Europe, particularly among the young people. To counteract this, the EU launched the actions aimed at prevention of the youth unemployment (Bratti et al., 2018). One of the reasons the young people find it difficult to integrate into the labour market is the "expectingap" that exists between the employer and the younger generation (Vilka \& Pelse, 2012). As a major cause of high youth unemployment in Spain (46.1\% in 2011), Garcia sees a lack of the coordinated actions between the education institutions and the labour market (Garcia, 2011). In the Western Balkans - Macedonia, Serbia, and Montenegro, on the other hand, a job placement is influenced by the age of the youngster, the level of education of the parents, and the financial situation of the family (Arifi \& Marmullanu, 2019). The authors agree with the researchers that there is a link between the parents' education level and the young person's employability, as the parents motivate young people to acquire education.

There are different views on the impact of the training on job placement: the impact of the training is lower when unemployment level is low, in turn, in a long-term when the unemployment level is high (Lechner \& Wunsch, 2009), on-the-job training leads to stable employment compared to other training programs (Feracci at al., 2017). The authors agree that the trainees that have completed on-the-job training are more prepared for the labour market, as they face the practical reality during the training process and acquire the practical skills needed in the particular profession. The research in Latvia indicate that the training measures at the operational level are incapable of responding to what is happening in the labour market. There is a risk that training (at least in the case of specific vocational training) is provided at a time when there is no longer any need for it. Training in Latvia is perceived as a social support measure providing material support in addition to knowledge acquisition (Barbare, 2013). Finding a job is not the 
main motivation for training, as only $58 \%$ of the unemployed trainees plan to use the acquired knowledge in practice (Laskova \& Brokane, 2014). The adult education provides opportunities to improve or adapt the skills of unemployed people and promotes social inclusion (Stalidzane, 2015).

The authors conclude that participation in the training programs can help the unemployed individuals to return to the labour market, still, quality of the training is affected by a number of negative factors - the pursuit of profit by the educational institutions, the use of unemployed training as a measure for replacement of employment, lack of correspondence of the training programs to the labour market demands because of delayed implementation.

The unemployment rate in Latvia tends to decrease - it was $7.4 \%$ in 2018, while the average unemployment rate in Latgale region in 1996-2018 was by $6.8 \%$ higher than the average in other regions of Latvia (CSB, 2019). It has also been noticed by the OECD that the unemployment and poverty are much higher in the eastern part of Latvia, especially in Latgale region, compared to Riga or Pieriga region (OECD, 2017). By decreasing the total number of the unemployed persons in 2015-2018, the number of long-term unemployed has decreased to $25 \%$ of the total number of unemployed persons; still $55 \%$ of all long-term unemployed are located in Latgale (SEA, 2019).

High long-term unemployment can lead to an increase in structural unemployment. The unemployed individuals consider the potential gains and losses and sometimes decide not to work. The unemployment status for many individuals is necessary to receive a benefit, which allows qualifying for a municipal support (Niklass, 2013). The authors conclude that access to the municipal benefits does not motivate the long-term unemployed individuals to enter the labour market.

In Latvia, at the end of period of 2015-2018, among the unemployed persons registered in the SEA the largest share is the individuals having secondary vocational education (on average $36 \%$ of all unemployed) and individuals in the age groups 55-59 and 50-54 (SEA, 2019). The authors conclude that the unemployed of this age group have not been able to adapt to the demands of the labour market and some of them are reluctant to do so because they do not understand the market economy. It should also be noted that one in fifteen young people $(6.8 \%)$ was unemployed, while the youth unemployment rate was $18 \%$, which is the highest among all age groups (SEA, 2019).

In order to reduce unemployment and help people to enter the labour market, Latvia has access to the ESF funding, which is used by the SEA for training the unemployed. 


\section{Evaluation of the training programs for the unemployed implemented by SEA}

In this study, the economic effectiveness of the use of financial resources for training of the unemployed will be measured by the number of persons entering training and entering the labour market within six months after the training, the cost of training per trainee and per person employed after the training.

During the research period, training activities have been carried out within the framework of two ESF projects - "Youth Guarantees" and "Support for Education of Unemployed". The training programs for the unemployed are approved by the Training Commission of the Ministry of Welfare. The programs included in the list of approved training programs are implemented in the whole territory of the country, without taking into account the differences of the regions of Latvia, which would be based on the medium-term regional development.

The measure "Training at the Employer's" has a higher economic efficiency, because legal employment relations are establish with the trainee during the training, thus reducing the risk of benefit dependency. In total, 1038 unemployed persons were involved in the measure "Training at the Employer's" and the engagement rate increased in 2018, when the grants to the employers increased. The average cost of this training is EUR 2050 per trainee. However, these costs are fed back into the national budget, as the wages of the trainees are tax deducted and paid.

The authors have conducted several expert interviews to evaluate the economic efficiency of the funding spent on education of the unemployed. The employers' opinions on the SEA measure "Training at the Employer's" were surveyed, selecting four employers involved in this measure that have trained employees for the needs of their companies during 2015-2018. The experts do not regard the applicant's previous higher education or previous vocational training at the SEA as a prerequisite for involving the unemployed person in the training. It can be concluded that the unemployed individuals involved in this measure are motivated to acquire new skills, which would help to maintain the job, and they obey the discipline at workplace. The experts mention that people are afraid to work with new, modern equipment with computerized management systems and some of the unemployed persons just use the privileges offered by the SEA, but do not want to work. All experts would recommend other employers to train their employees using this measure, which shows that the funding used for this measure is of high economic efficiency.

In order to evaluate if the vocational and non-formal education programs are up-to-date and to assess the motivation of the unemployed, the 
authors have interviewed experts of four educational institutions implementing training measures at the SEA Balvi branch. The interviews show that although the unemployed trainees are motivated to acquire knowledge, some of them engage in training just to provide themselves with a temporary source of income in the form of a stipend. This fact indicates that the financial resources spent on training of the unemployed persons in vocational and non-formal education programs are moderately costeffective.

\section{Integration of the unemployed into the labour market after training}

It is necessary to have the demand in labour market in order to ensure that the trained persons could enter employment. The number of vacancies registered by the SEA is increasing every year: in $2015-2018,50 \%$ of all vacancies were registered in Riga, but the least vacancies were registered in Pieriga (8\%). In the other regions, $19 \%$ of all vacancies of the region were registered in the large cities (SEA, 2019c). The SEA does not have the information on the denials of vacancies offered to the unemployed. The authors recommend that if an unemployed person has refused the offered vacancy that corresponds with the training program acquired at the SEA, the application for his/her further training should not be registered. This approach to registering applications will reduce the number of unemployed who wish to repeatedly use the training provided by the SEA but do not wish to re-enter the labour market.

The SEA do not collect data on the occupations in which the unemployed trainees have found employment, so it is not possible to conclude whether participation in the training program and the knowledge gained have contributed to finding the employment or whether it is accidental. The authors recommend that the SEA improve the inter-institutional exchange of personal data, which will make it possible to gather data on the occupations in which the unemployed have established themselves in order to evaluate the effectiveness of the training programs.

The Training Commission remove from the list the training programs with a low number of unemployed persons involved, but high number of the persons employed in relation to the number of persons involved. Thus, the training measures are geared to the quantity and not the quality of the trainees. The main aim and quality indicator of the SEA training shall be the unemployed trainees that have returned to the employment. The new programs included in the Commission's list are inactive for a long time and the unemployed persons cannot be involved.

Active measures of the labour market policies are primarily targeted at those groups of the unemployed who find it most difficult to return to the 
labour market, those without the means of subsistence. On the other hand, such involvement in the employment measures seems to lower the success rate of the active labour market policy measures (job placement after training, etc.) and does not allow motivated unemployed individuals to return to the employment more quickly and to return the funds invested in their education through tax and added value of labour. The repeated participation of the long-term unemployed individuals in training programs is not cost-effective, it is demonstrated by the high number of the individuals re-enrolling in training, for example, in 2015-2018 there were 316 persons that had participated in the ESF project "Support for Education of Unemployed" training activities 5-7 times.

The authors have analysed the performance indicator of the ESF projects - the share of the trainees that have been employed within six months after the training activities (Figure1).

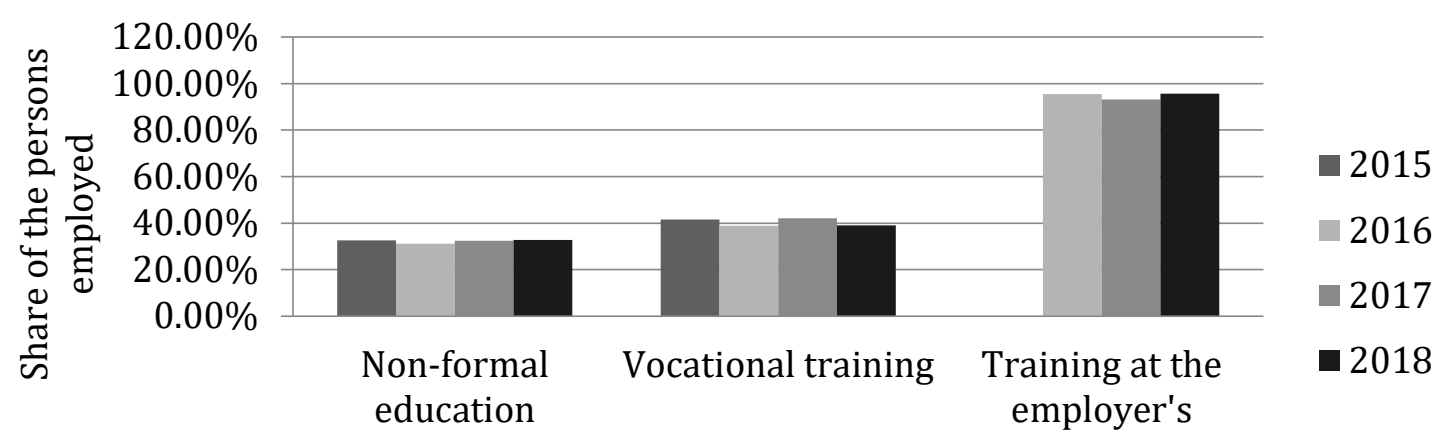

Training measures

Fig.1 The share of the trainees employed within six months after participating in the ESF training activities in 2015-2018, \% (by the authors, based on MoW, 2016; MoW, 2017; MoW, 2018; SEA, 2019a)

The highest rate of job placement is after participation in the measure "Training at the Employer's" (94.8\%), but only 2\% of the total number of trainees are involved in this particular measure. In turn, the lowest rate of the employment (32.8\% of trainees) is after the non-formal education programs where the largest number of participants are involved.

The authors have carried out correlation and regression analysis to determine the correlation between training and job placement. There is a positive and linear relationship between the unemployed persons' participation in training and job placement afterwards ( $\mathrm{r}=0.978)$ showing close relationship. This is also confirmed by the estimated coefficient of determination $\mathrm{R}^{2}=0.957$. There is a strong correlation between the indicators in all regions of Latvia, as the correlation coefficient $r$ ranges from 0.981 in Vidzeme region to 0.997 in Kurzeme region. The relationships examined are positive and, in all regions, training for the unemployed has an impact on job placement within six months after the training. 
The most successful in finding job placement after the training are the unemployed trainees in Riga and Pieriga regions $(46 \%$ of the unique trainees). In Latgale region, this number is only $23 \%$ of the unique trainees (Figure 2).

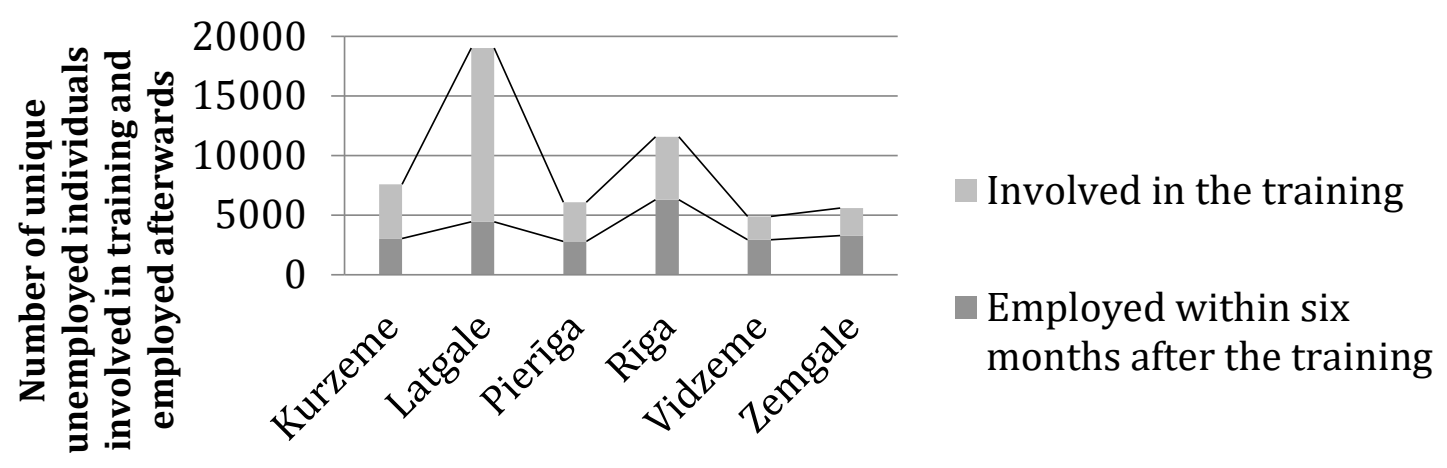

Statistical regions

Fig.2 Number of the unemployed persons trained within ESF project "Support for Training of Unemployed" and number of trainees employed within 6 months after the training in 2015-2018 in statistical regions of Latvia

(by the authors, based on SEA, 2019; SEA, 2019b)

The authors have estimated the cost of one trainee, who has found a job placement, in relation to the funding used for training in statistical regions of Latvia (Figure 3).

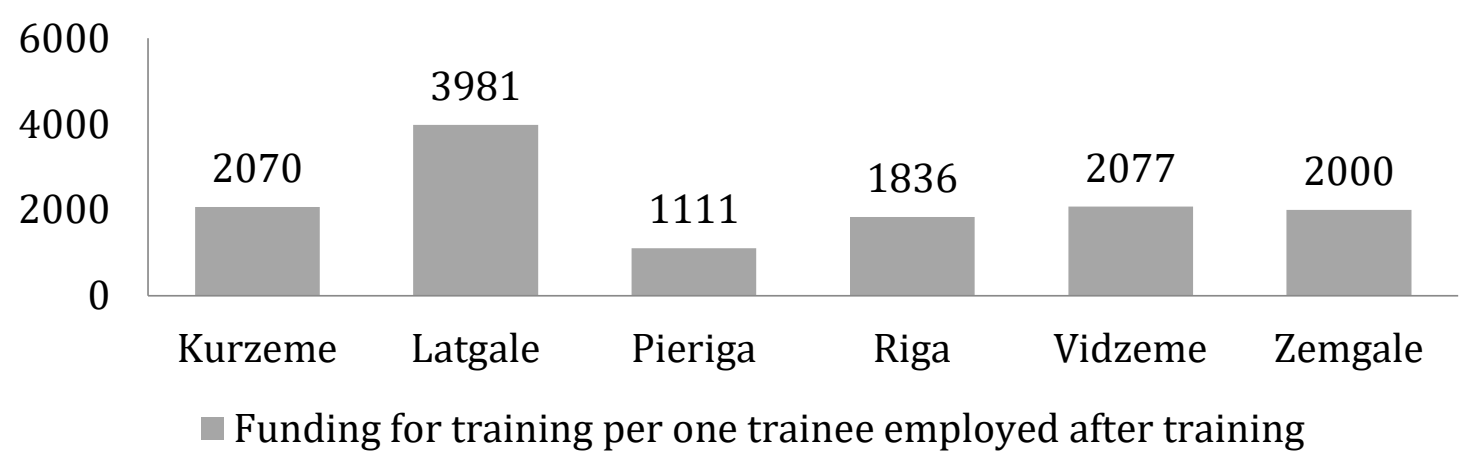

Fig.3 Funding used for training in statistical regions per one trainee employed after training in 2015-2018 (by the authors, based on SEA, 2019; MoW, 2017; MoW, 2018)

The most cost-effective training is in Pieriga region. Latgale, on the other hand, is using funding inefficiently, as EUR 3981 is spent per one unemployed trainee who finds a job, which is 3.5 times more than in Pieriga region.

The analysis of variance on job placement of the unemployed persons participating in the training measures within the project "Support for Training of Unemployed" in the statistical regions of Latvia in 2015-2018 
show that the regions have impact on the job placement of the unemployed persons. While in Latgale, according to the analysis, every fourth or fifth unemployed person finds a job after the training; in other regions of Latvia, about $40 \%$ of those involved in training find a job.

\section{Conclusions and suggestions}

1. The implementation of quality training programs is influenced by a number of negative factors - the pursuit of profit by the educational institutions, use of training as a substitute for employment, the inadequacy of training programs for the needs of the labour market.

2. The differences in unemployment rates in the statistical regions of Latvia have increased significantly. Of all the long-term unemployed persons registered at the SEA, the highest proportion is in Latgale (55\%). The SEA does not collect information on denials of vacancies offered to the unemployed. The authors recommend that if an unemployed person has refused a vacancy that corresponds to the training program acquired at the SEA, their application for further training shall not be registered.

3. When approving the programs, the Training Commission does not take into account their relevance to the labour market needs of each region. They should be differentiated according the medium-term regional development needs. The Training Commission should keep non-formal education and vocational training programs that have a high proportion of the trainees being employed after the training.

4. $94.8 \%$ of the trainees have been employed after participating in the measure "Training at the Employer's". This measure is positively evaluated by the employers surveyed. The Ministry of Welfare and the SEA, when planning the allocation of funds for training activities, starting with 2020, should provide more participants and funding for this activity.

5. There is a strong and positive correlation between the participation in the training and the job placement after the training across the country and in particular regions. The hypothesis that the participation of the unemployed persons in training programs facilitates their return to the labour market has been confirmed. However, it is not possible to determine whether the employment of the trainees has been indorsed by the knowledge acquired in the training implemented by the SEA, because the SEA does not have information about the professions in which the trainees have been employed afterwards.

6. The economic efficiency of the use of financial resources for the training of the unemployed persons in terms of the number of trainees employed and of training costs is high in Pieriga region, where $46 \%$ of the 
unemployed trainees have found a job after training; thus, the funding for training per one person employed after the training is EUR 1111. In turn, in Latgale region, only $23 \%$ of the trainees have been employed after the training, consequently the costs are EUR 3981 per one trainee who has been employed afterwards. Therefore, the hypothesis that the funding of training programs for the unemployed organized by the SEA has a high economic efficiency has been confirmed partially.

\section{References}

1. Aysina, R. M., Maksimenko Z. A., Nikiforov, M. V. (2016). Feasibility and Efficacy of Job interview Simulation Training for long-term Unemployed Individuāls PsychNology Journal, 14 (1), 41-60.

2. Arifi, A., Marmullaku, B. (2019). Youth Labor Market Transition Challenges in Western Balkans: the case of Macedonia, Serbia and Montenegro. European Scientific Journal, 15 (5), 154-162.

3. Barbare, I. (2013). Nodarbinātības valsts aǵentūras apmācību pasākumu atbilstība Latvijas darba tirgus vajadzībām. Starptautiskās zinātniskās konferences materiāli. Sabiedrība. Integrācija. Izglītība, 2, 291-301.

4. Bratti, M., Ghirelli, C., Havari, E., Santangelo, G. (2018). Vocational Training for Unemployed Youth in Latvia: Evidence from a Regression Discontinuity Design. IZA Institute of Labor Economics, Discussion Paper Series IZA DP, 11870. Retrieved from http://ftp.iza.org/dp11870.pdf

5. Feracci, M., Fougere, D., Rain, A. (2017). The Impact of Training Programs Content on Unemployment Duration In France. 66TH Annual Congress of the French Economic Association. Retrieved from https://afse2017.sciencesconf.org/141483/ document

6. Garcia, J.R. (2011). Youth Unemployment in Spain: Causes and Solutions. BBVA reseach. Retrieved from https://www.bbvaresearch.com/KETD/fbin/mult/WP_11 31_tcm348-270325.pdf

7. Griṇeviča, L. (2016). Jauniešu bezdarba ietekmējošo faktoru analīze Latvijā, promocijas darba kopsavilkums. Pieejas veids: http://llufb.llu.lv/dissertationsummary/regional-economics/LivaGrinevica_prom_darba_kopsav2016_ LLU_ESAF.pdf

8. Hazans, M. (2005). Unemployment and the Earnings Structure in Latvia. World Bank. Retrieved from https://elibrary.worldbank.org/doi/abs/10.1596/18139450-3504

9. Hodzic, S., Ripoll, P., Bernal, C. (2015). The Effect of Emotional Competences Training Among Unemployed Adults: Longitudinal Study. Applied psychology: Health and Well - Being, 7 (3). pp.275-292.

10. Laskova, J., Brokane, L. (2014). Opportunities and motivation for training unemployed in Latvia. $5^{\text {th }}$ World Conference on Education Sciences - WCES, Procedia - Social and Behavioral Science, 116, 649-655.

11. Laškova, J. (2012). Bezdarbnieku izglītošanas iespējas Latvijā. Starptautiskās zinātniskās konferences materiāli. Sabiedrība. Integrācija. Izglītība, 1, pp.503-514.

12. Latvijas Nacionālais attīstības plāns 2014.-2020. (2012). Latvijas Republikas Saeima. Pieejas veids: https://www.pkc.gov.lv/sites/default/files/inline-files/20121220_ NAP2020\%20apstiprinats\%20Saeima_4.pdf 
13. Latvijas Republikas Centrālā statistikas pārvalde (CSB) (2019). Bezdarba lìmenis pēc tautības un dzimuma. Pieejas veids: http://data1.csb.gov.lv/pxweb/lv/ sociala/sociala_nodarb_bezdarbs_ikgad/NBG022.px/table/tableViewLayout1/? rxid=a39c3f49-e95e-43e7-b4f0-dce111b48ba1

14. Latvijas Republikas Labklājības ministrija (MoW) (2017). Par darba tirgus īsterminga prognozēm 2017. gadam un bezdarbnieku un darba meklētāju prioritārajiem apmācību virzieniem. Pieejas veids: http://www.lm.gov.lv/upload/darba_tirgus/ a/lmzino_19052017.pdf

15. Latvijas Republikas Labklājības ministrija (MoW) (2016). Par darba tirgus ìsterminga prognozēm 2016. gadam un bezdarbnieku un darba meklētāju prioritārajiem apmācību virzieniem. Pieejas veids: http://www.lm.gov.lv/upload/darba_tirgus/ lmzino_2016_31032016.pdf

16. Latvijas Republikas Labklājības ministrija (MoW) (2018). Par bezdarbnieku un darba meklētāju apmācību rezultātiem 2017. gadā un prioritārajiem apmācību virzieniem. Pieejas veids: http://www.lm.gov.lv/upload/darba_tirgus/ a/lmzino_2018.pdf

17. Lechner, M., Wunsch, C. (2009). Are Training Programs More Effective When Unemployment Is High? Journal of Labor Economics, 27 (4), 653-692.

18. Niklass, M. (2013). Jauniešu ar zemu izglītību iekḷaušanās darba tirgū Latvijā, promocijas darbs. Pieejas veids: https://www.szf.lu.lv/fileadmin/user_upload/szf_ faili/Petnieciba/promocijas_darbi/Mareks\%20Niklass_2013.pdf

19. Nodarbinātības valsts aǵentūra (SEA) (2019). ESF projekta „Atbalsts bezdarbnieku izglītībai" Informācija par uzsāktajām dalībām no projekta sākuma līdz 31.12.2018(profesionālā apmācība, neformālā izglītība, praktiskā apmācība pie darba devēja).[NVA iekšējie statistikas dati].

20. Nodarbinātības valsts aǵentūra (SEA) (2019a). Pārskats par bezdarba situāciju valstī (decembris). Pieejas veids: http://www.nva.gov.lv/docs/31_5c5066faa142f5. 77210853.pdf

21. Nodarbinātības valsts aǵentūra (SEA) (2019b). ESF projekti (2014.-2020. gads). Pieejas veids: http://www.nva.gov.lv/index.php?cid=2\&mid=511

22. Nodarbinātības valsts aǵentūra (SEA) (2019c). Statistika. Pieejas veids: http://www.nva.gov.lv/index.php?cid=6

23. OECD (2017). Economic Surveys: Latvia. OECD Publishing. Retrieved from http://www.oecd.org/economy/surveys/Latvia-2017-OECD-economic-surveyoverview.pdf. .

24. Schonauer, C. (2016). Economic and Social Factors Influence on Unemployment in Romania at the Local Level. Computational methods in Social sciences, 4 (2), pp.5459.

25. Sfichi, E., D., Bratiloveanu, A. (2017). Correlations between Labor Employment and Economic Growth „Ovidius” University Annals. Economic Sciences Series. 17 (1), pp.242-247.

26. Stalidzāne, G. (2015). Career Development Theories for the Education of Unemployed. Proceedings of the Internetional Scientific Conference. Society. Integration. Education, 4, pp.224-232.

27. Vilka, L., Pelse, I. (2012). Deficiency of Employability Capacity. SHS Web of Conference 2. Retrieved from https://www.shs-conferences.org/articles/shsconf/ pdf/2012/02/shsconf_shw2010_00039.pdf 